\title{
Development and Application of Dam Safety Monitoring Automatic System of Xianlin Reservoir
}

\author{
Yao Kangkang1,a, Zhang yulun², Gao chao², \\ Fangxushun ${ }^{4}$, Hou Wenang ${ }^{5}$ \\ 1,2,3 Xianlin Reservoir Management Institute, Hangzhou, China \\ ${ }^{4,5}$ Nanjing Hydraulic Research Institute \\ a523110265@qq.com
}

Keywords: Reservoir safety, automatic monitoring

Abstract: The paper introduces the structure, composition, monitoring point arrangement, instrument use and information management system of the automatic monitoring system of Xianlin Reservoir.

\section{Project overview}

Xianlin Reservoir project is located in Xianlin Town, Yuhang District, Hangzhou City. The project task focuses on providing urban emergency standby water supply and salinity-resisting water supply, coupled with floor control and water environment improvement, etc. The dame lies in Zhutianwu Village of Xianlin Town. It can store water of $62.5 \mathrm{~m}$ at normal time. The total storage is $9,990,000 \mathrm{~m}^{3}$. Dam type adopts concrete-faced rock-fill dam. The release structure adopts bottom outlet tunnel spillway. The overall length of outlet tunnel is $15,122 \mathrm{~m}$ and part in "water diversion to city" project is $2,234 \mathrm{~m}$ long and close channel is $2,146 \mathrm{~m}$ long. The overall length of newly opened tunnel is $10,742 \mathrm{~m}$ and the diameter of the lining tunnel is $3.5 \mathrm{~m}$.

Xianlin Reservoir project mainly adopts pressurized water conveyance. It conveys water to desilting basin in virtue of the fall between Xianlin Reservoir and desilting basin of water intake tunnel of "water diversion to city" project (regions crossing the "water diversion to city" project adopt non-pressure water conveyance), then delivers water to Shanhusha Reservoir through pipeline from Dadaosha pump station. The water-carrying capacity is $25 \mathrm{~m}^{3} / \mathrm{s}\left(35 \mathrm{~m}^{3} / \mathrm{s}\right.$ in long term); when Xianlin Reservoir needs to supplement water, it is necessary to launch the Daqinggu pump station according to need and take water from the main hole of the "water diversion to city" project through water channel so as to supplement water to the Xianlian Reservoir. The water supplement capacity is $5 \mathrm{~m}^{3} / \mathrm{s}$

\section{Monitoring project overview}

Monitoring project mainly includes four parts: deformation monitoring, traffic monitoring, panel stress-strain monitoring and environmental variables monitoring.

The design is based on Dam Safety Monitoring Automatic Technical Specification DL/T5211-2005. 


\begin{tabular}{|c|c|c|c|c|c|c|}
\hline $\begin{array}{c}\text { On-site } \\
\text { monitorin } \\
\text { g station } \\
\text { No. }\end{array}$ & $\begin{array}{c}\text { On-site } \\
\text { monitoring } \\
\text { station } \\
\text { location }\end{array}$ & $\begin{array}{c}\text { Monitoring } \\
\text { instrument } \\
\text { name }\end{array}$ & $\begin{array}{c}\text { Monitorin } \\
\text { g point } \\
\text { No. }\end{array}$ & Instrument type & $\begin{array}{l}\text { Monitorin } \\
\text { g point } \\
\text { quantity of } \\
\text { access } \\
\text { automatic } \\
\text { system }\end{array}$ & Remarks \\
\hline \multirow{8}{*}{ DB1 } & \multirow{8}{*}{$\begin{array}{l}\text { Grouting } \\
\text { footrill in } \\
\text { left bank } \\
\text { of dam }\end{array}$} & $\begin{array}{l}\text { One-way } \\
\text { joint meter }\end{array}$ & $\mathrm{J} 1 \sim 5$ & $\begin{array}{c}\text { Potentiometer-typ } \\
\mathrm{e} \\
\end{array}$ & 5 & \\
\hline & & $\begin{array}{l}\text { Three-way } \\
\text { joint meter }\end{array}$ & $\mathrm{J}^{3} \mathrm{f} 1 \sim 2$ & $\begin{array}{c}\text { Potentiometer-typ } \\
\mathrm{e} \\
\end{array}$ & 6 & \\
\hline & & Osmometer & $\begin{array}{c}\text { UP1 3、 } \\
\text { UP7 }\end{array}$ & $\begin{array}{l}\text { Vibrating } \\
\text { wire-type }\end{array}$ & 4 & \\
\hline & & $\begin{array}{c}\text { Steel rebar } \\
\text { meter }\end{array}$ & $\mathrm{R} 1 \sim 5$ & $\begin{array}{l}\text { Vibrating } \\
\text { wire-type }\end{array}$ & 5 & \\
\hline & & $\begin{array}{c}\text { Two-way } \\
\text { extensometer }\end{array}$ & $S^{2} b 1 \sim 2$ & $\begin{array}{l}\text { Vibrating } \\
\text { wire-type }\end{array}$ & 4 & \\
\hline & & $\begin{array}{c}\text { Three-way } \\
\text { extensometer }\end{array}$ & $S^{3} b 1$ & $\begin{array}{l}\text { Vibrating } \\
\text { wire-type }\end{array}$ & 3 & \\
\hline & & $\begin{array}{c}\text { No stress } \\
\text { meter }\end{array}$ & $\mathrm{N} 1 \sim 3$ & $\begin{array}{l}\text { Vibrating } \\
\text { wire-type }\end{array}$ & 3 & \\
\hline & & $\begin{array}{c}\text { Weir } \\
\text { transducer }\end{array}$ & WE1 & & 1 & $\begin{array}{l}\text { Meed to } \\
\text { configur } \\
\text { e sensor }\end{array}$ \\
\hline \multirow{8}{*}{ DB2 } & \multirow{8}{*}{$\begin{array}{l}\text { Grouting } \\
\text { footrill in } \\
\text { right bank } \\
\text { of dam }\end{array}$} & $\begin{array}{c}\text { Free air } \\
\text { temperature } \\
\text { gauge }\end{array}$ & & & 1 & \\
\hline & & Rain gauge & & & 1 & \\
\hline & & $\begin{array}{c}\text { Thermomete } \\
\mathrm{r}\end{array}$ & $\mathrm{T} 1 \sim 5$ & $\begin{array}{l}\text { Vibrating } \\
\text { wire-type }\end{array}$ & 5 & \\
\hline & & $\begin{array}{l}\text { Water level } \\
\text { indicator }\end{array}$ & Psw1 & & 1 & \\
\hline & & Osmometer & $\begin{array}{l}\text { P1 8、 } \\
\text { UP4 6、 } \\
\text { UP8 11 }\end{array}$ & $\begin{array}{l}\text { Vibrating } \\
\text { wire-type }\end{array}$ & 15 & \\
\hline & & $\begin{array}{l}\text { One-way } \\
\text { joint meter }\end{array}$ & $\mathrm{J} 6 \sim 10$ & $\begin{array}{c}\text { Potentiometer-typ } \\
\text { e } \\
\end{array}$ & 5 & \\
\hline & & $\begin{array}{l}\text { Two-way } \\
\text { joint meter }\end{array}$ & $\mathrm{J}^{2} \mathrm{f} 1 \sim 2$ & $\begin{array}{c}\text { Potentiometer-typ } \\
\text { e } \\
\end{array}$ & 4 & \\
\hline & & $\begin{array}{l}\text { Three-way } \\
\text { joint meter }\end{array}$ & $\mathrm{J}^{3} \mathrm{f} 3 \sim 4$ & $\begin{array}{c}\text { Potentiometer-typ } \\
\mathrm{e} \\
\end{array}$ & 6 & \\
\hline HJD1 & $\begin{array}{c}0+025.00 \\
\mathrm{~m}\end{array}$ & Osmometer & UPhjd1 2 & $\begin{array}{l}\text { Vibrating } \\
\text { wire-type }\end{array}$ & 2 & \\
\hline STN1 & $\begin{array}{c}0+015.00 \\
\mathrm{~m}\end{array}$ & Osmometer & UPstn1 2 & $\begin{array}{l}\text { Vibrating } \\
\text { wire-type }\end{array}$ & 2 & \\
\hline
\end{tabular}




\section{Monitoring automatic system composition}

Data acquisition is the most basic and important link in the safety monitoring of dam. The automatic system is able to monitor the dam safety performance and analyze monitoring model data after acquisition. Also, analysis result can be conveyed to network interface through database followed by real-time publication. If there is abnormal value, automatic system can achieve automatic alarm so as to remind the administrator to check and take measures accordingly.

\section{Monitoring automatic system structure}

The dam monitoring system adopts distributed architecture which can effectively ensure the stability and reliability of the who system. If single monitoring unit suffers problems, other units will not be impacted. The The automatic acquisition system of monitoring data is composed of monitoring station (with one or more monitoring units), communication device, control circuit, power circuit, acquisition computer, data acquisition software and GRRS communication terminal, solar energy device and so on. The whole system has one monitoring management key station and four on-site monitoring stations.

\section{Monitoring function}

The system is equipped with multiple data acquisition ways and measurement control ways. Data acquisition ways include reconnaissance measurement, cyclical measurement and timing measurement. Also, manual measurement is available on on-site measurement and control unit. There are two measurement control ways, namely central control (response type) and automatic control (self-report type), The two measurement control ways are used to collect data in various sensors. Each sensor is set with security line. Once the measured value exceeds the line, the system can alarm automatically.

The monitoring arrangement diagram, arrangement diagram of monitoring control points, monitoring value hydrograph, monitoring data distribution diagram, monitoring information in monitoring points and alarm status can be seen in the monitoring system. Also, data storage system is able to store and backup data automatically, which ensures the security of parameters and data in memory if the power supply system suffers accident.

Measurement and control unit is directly connected with sensor. It can be controlled, monitored and managed by the monitoring management key station. With no need to follow indicator from acquisition machine, measurement and control unit can conduct automatic patrol monitoring and storage according to set time using automatic control way, and send data monitored to the acquisition machine for backup and storage. Each measurement and control unit is equipped with interface for manual measurement which can be connected to the portable measuring instrument and portable computer for collecting monitored data.

\section{Monitoring data information management system}

The acquisition software is matched with automatic data acquisition unit. It has six parts, namely data online acquisition, electric-measuring result computing, statement and graphic output of data in monitoring point, acquisition feedback and control, remote monitoring, information report, etc. Each part has its own user interface which can not only coordinate with safe monitoring information management and comprehensive analysis system but also work independently.

The system includes a database server which is used to store various engineering safety information. SQL Server2008 is taken as the management system of database. The monitoring data, system parameter and other material information are stored in the back-end database server, so as to 
achieve information sharing. Only system administrator can manage the database on server. Users can only operate database on client. This ensures the security and accuracy of data.

Information management system software includes information management analysis software, Web information publish software, deformation measurement processing software and interface software which provides data interface for the further analysis of data.

\section{Automatic system data acquisition and examination}

The stability of monitoring automatic system is very important. Stable system can ensure stable and safe operation as well as guarantee the reliability.

\section{System operation stability requirement:}

1) Monitoring data during test run period shall enjoy good continuity and periodicity, and there is no systematic bias. These features can reflect the change rule of engineering monitoring objects;

2) After comparison, automatic acquisition data and manual monitoring data shall have basically the same change rule and close change range;

3) Under the condition that the monitored physical quantity remains unchangeable, collect monitoring data for successive 15 times and calculate mean square error in the monitoring value, so as to test the stability of short-term monitoring value of the system.

\section{System reliability requirement:}

The MTBF and FR shall meet the requirement in Construction Contract, Bidding Document, Tender Document and Design Document.

The MTBF means the normal working time between two adjacent faults. The examination period usually refers to one year before the examination day.

Fault definition: If the monitoring value in controlled monitoring points is abnormal or monitoring stops for over 1 week because monitoring points can not work normally in a certain time (not due to sensor problem), the monitoring point suffers fault. If monitoring point can not work normally but recover within 1 week, it will not be accounted into "failure number" but into "failure day". The MTBF of acquisition system is the average value of MTBF of various monitoring points, with the calculation formula as follows,

$$
M T B F=\sum_{i=1}^{n} t_{i} /\left(\sum_{i=1}^{n} r_{i}\right)
$$

ti - the normal working hours of the $\mathrm{i}^{\text {th }}$ monitoring point (unit) during examination period;

ri - the failure time of the $\mathrm{i}^{\text {th }}$ monitoring point (unit) during examination period;

$\mathrm{n}$ - total number of monitoring points (units) in system

FR means the ratio of number of data unable to be measured due to own reason of automatic system to the number of data which should be measured during examination period,

$$
F R=N F / N M
$$

Where, 
$\mathrm{NF}$ - number of data unable to be measured

NM - number of data which should be measured

System manual comparing-monitoring index

Manual comparing-monitoring usually uses hydrograph or variance analysis for comparison.

Hydrograph comparison means to firstly collect the automatic monitoring value and manual monitoring value of a monitoring point at same time and in same measuring time and respectively draw the hydrograph of automatic monitoring value and manual monitoring value, followed by comparing the regularity and change extent.

Variance analysis means to firstly extract the automatic monitoring value and manual monitoring value of a monitoring point at same time and in same measuring time during the test run period and form the automatic monitoring value sequence and manually monitoring value sequence, followed by calculating the standard deviation $\sigma_{\text {自 }}, \sigma_{\text {人 }}$; then set the automatic monitoring value as $X_{\text {自 } i}$ and manual monitoring value as $X_{{ } i}$, thus the difference value between them is,

$$
\begin{gathered}
\text { Assuming } \delta \leq 2 \sigma, \text { the } \begin{array}{c}
\delta_{i}=\left|X_{\text {自 } i}-X_{\text {人 } i}\right| \text { mean square error is, } \\
\sigma=\sqrt{\left(\sigma_{\text {自 } i}^{2}+\sigma_{\text {人 } i}^{2}\right)}
\end{array}
\end{gathered}
$$

Where,

$\sigma_{\text {自 }}$ is the automatic measurement accuracy and $\sigma_{\curlywedge}$ is the manual measurement accuracy.

\section{Conclusion}

The safety monitoring system of Xianlin Reservoir realizes monitoring automation. By applying the automatic monitoring system, we conduct real monitoring and data analysis on the safety and reliability of hydraulic structure. The status and safety situation are shown in the webpage. Also, professional personnel is able to operate the system remotely relying on remote operation system which greatly reduces labor cost and time cost, lowers monitoring risk, promotes the modernized management and operation level of dam monitoring as well as improves social and economic profit. After one year of operation, the system is proved to be able to work stably and reliably, which provides the first-hand data for dam monitoring.

\section{Acknowledgements}

Thins work was financially supported by the National Institute Research Funding(Y316024)

\section{References}

[1]. People's Republic of China Electric Power Industry Standard. Specification for Rolled Earth-rockfill Dam Construction DL/T5129-2001, Beijing: China electric power press, 2001

[2]. B. Holfmann Wellenhof, H. Lichtenegger and J. Collins, GPS Theory and Practise, New York: 
Springger Wien, 1997

[3]. Safety provision and an expert system for diagnosing and predicting dam behavior[J] . E. G. Gaziev. Hydrotechnical Construction . 2000 (6) 